http://journals.ums.ac.id/index.php/ijolae

\title{
The Chemistry Competency Achievement of SMA Negeri 7 Palu Students Using Predict, Observe, and Explain (POE) Learning Model
}

\author{
Ijirana $^{1}$, Sri Wahyuni ${ }^{2}$ \\ ${ }^{1,2}$ Teacher and Education Faculty, Tadulako University, Indonesia
}

DOI: 10.23917/ijolae.v1i1.7474

Accepted: Januari $7^{\text {th }}, 2019$. Approved: January $31^{\text {st }}, 2019$. Published: March $4^{\text {th }}, 2019$

\begin{abstract}
This study is aimed to derive a description of learning result improvement on salt hydrolysis material by implementing POE (Predict, Observe, Explain) learning model on the students of grade XI at SMA Negeri 7 Palu. This study was a pre-experimental within Static Group Comparison design. Sampling was carried out in a simple random with class XI MIA 1 as the experiment class and XI MIA 5 as the replication class. The instruments used in this study divided into 3 competencies, the affective competency using an observation sheet, the psychomotor competency using self-assessment questionnaire and the cognitive competency using a final test. Statistical inferential analysis using t-test one right side by requiring normal and homogeneous data. The average psychmotor competency of students in the XI MIA 1 is 81 , whilst for replication class is 79. The average cognitive competency of students in XI MIA 1 is 77 with deviation standard of 10.55, whilst for replication class is 75 with standard deviation of 12.98. The result of hypothesis test using t-test one right side is $t_{\text {calculated }}>t_{\text {table }}$ or $3.32>1.71$, whilst for replication class is $1.85>1.72$, so $\mathrm{H}_{0}$ was rejected. This result concludes that the implementation of POE learning model in Grade XI students at SMA Negeri 7 Palu improves learning achievement on salt hydrolysis material to be more than competency minimum standard of 70 .
\end{abstract}

Keywords: POE Learning Model, Salt Hydrolysis Material, Cognitive Competency, Affective Competency and Psychomotor Competency

Corresponding Author:

Ijirana, Teacher and Education Faculty Tadulako University, Indonesia

Email: ijiranarizal@yahoo.co.id

\section{Introduction}

Chemistry is one of the difficult studies to be understood by students, in terms of mathematics calculation, concept and application (Johnstone and Otis, 2006). The statement is strengthened by research (Royal Institute of Chemistry in Anisa, et. al., 2013) that most of students in England admit the chemistry study is difficult though interest. The difficulty of students to understand and apply the chemical concepts affects the students to take the fastest steps by memorizing (Johnstone and Otis, 2006). It effects to the concept being studied tends to be not last long and easily lost, even sometimes the students do not understand the concept being studied (Shofiah, dkk., 2007). The difficulties faced by students to understand the certain concepts lead to the low result of learning outcomes, both in process and product of learning. One of phenomena found towards students of SMA Negeri 7 Palu, the data show that less than $50 \%$ of students who attain the minimum of completeness standard especially in teaching the material of salt hydrolysis. The average score in the material is only 66.67 lower than the minimum standard of 70 . 
Muslimah and Nurdiniah (2017) stated that the salt hydrolysis material is related to the abstract concept, then applied by calculation. The abstract concepts are hydrolized salt in water and the $\mathrm{pH}$ of the salt solution. The abstract concepts require the student observation by observing symptoms, classifying, hypothesizing, explaining and concluding (Iqbalia, 2015). Minimum basic competency of 2013 curriculum that should be attained in salt hydrolysis lesson is to analyze salts undergoing hydrolysis, to plan, to do, to conclude and to present the result of the research in order to determine types of salts undergoing hydrolysis. It shows that the learning on salt hydrolysis requires strategy of learning by observing the salts undergoing hydrolysis based on the characteristics, giving explanation of the phenomena to result conclusion.

According to Malik, et. al. (2015), teaching the abstract concept by observing the object phenomena through research would encourage the students critical thinking and gain direct experience of the activity. Related to the concept, Anisa et.al. (2013) stated that the implementation of POE (Predict, Observe, Explain) learning model would develop students scientific behavior and lead to be more active, critical and curious to what really happened. Therefore, the students may prove the abstract concepts by their own.

The POE learning model is a model where teachers explore the students understanding by instructing them to do three main tasks, first step is Predict, a process of students to observe the phenomena to be demonstrated by the teachers and predict the result. The second step is Observe, a process of students to demonstrate with teacher and note to what have been happened. The third step is Explain, a process of students to explain the different between initial hypothetic and the result of research within observation step (In- drawati and Setiawan, 2009). The learning experience could ease students to understand and remember the materials being learned that woud be impacted to increase the student concept comprehension (Sudesti, et. al., 2014). Therefore, POE learning model is implemented to increase the competency achievement of students learning about salt hydrolysis.

\section{Method}

This kind of research is Pre-experimental by using research design of Static Group Comparison (Creswell, 2013). The research was conducted in SMA Negeri 7 Palu, Sulawesi Tengah within 24 students of XI MIA 1 and 23 students of XI MIA 5 (replication class) being as the samples taken by Simple Random Sampling (Sugiyono, 2015).

The instruments used in the research is a questionnaire to measure the students psychomotor competencies given in the end of learning. The questionnaire consists of 15 questions as follows, students could explain the characteristics of salt hydrolyzed by water, students could observe the discoloration happened in litmus paper, students could classify 3 solutions into neutral, acidic and alkaline solution based on the solution discoloration, students could observe the $\mathrm{pH}$ of the solution by using universal indicator paper, students could use the drop pipette correctly, students could measure the $\mathrm{pH}$ of solution correctly in the correct steps, students summarize the experimental data based on the result of the practicum, students try to do the LKPD seriously, students often ask something unclear, students dare to criticize something wrong, students use the tools and materials according to the procedures, students inform the teachers when break the equipments, students could cooperate with partners in a group, students would accept criticism of the others and 
encourage to do self-correcting by themselves, students have cleaned laboratory equipments.

The multiple choices form of the test instrument has been validated for 20 items to measure the student cognitive competencies. One-tailed test is used to measure the progress of students cognitive competencies.

The data of psychomotor is assessed by Guttman measurement scale using the answer of "YES" to be scored as 1 and "NO" to be scored as 0 . The assessment of students psychomotor is using under formula below:

Psychomotor score $=\frac{\text { observed score }}{\text { expected score }} 100 \%$

The students psychomotor assessment result categorized as good under minimum score of 70 .

\section{Result and Discuss}

A. The Result of Student Psychomotor Competency Assessment Analysis

According to the research conducted, the result of psychomotor competency assessment as self-assessment questionnaire given to students of XI MIA 1 and XI MIA 5 (the replication) derives the average percentage of the entire students psychomotor aspects by implementing POE learning model as $81 \%$ and $79 \%$ for each. The data shows that the students of XI MIA 1 are categorized as highly skilled and students of XI MIA 5 (replication) as skilled. The average of analysis result of the students psychomotor competency for both classes have been shown in figure 1.

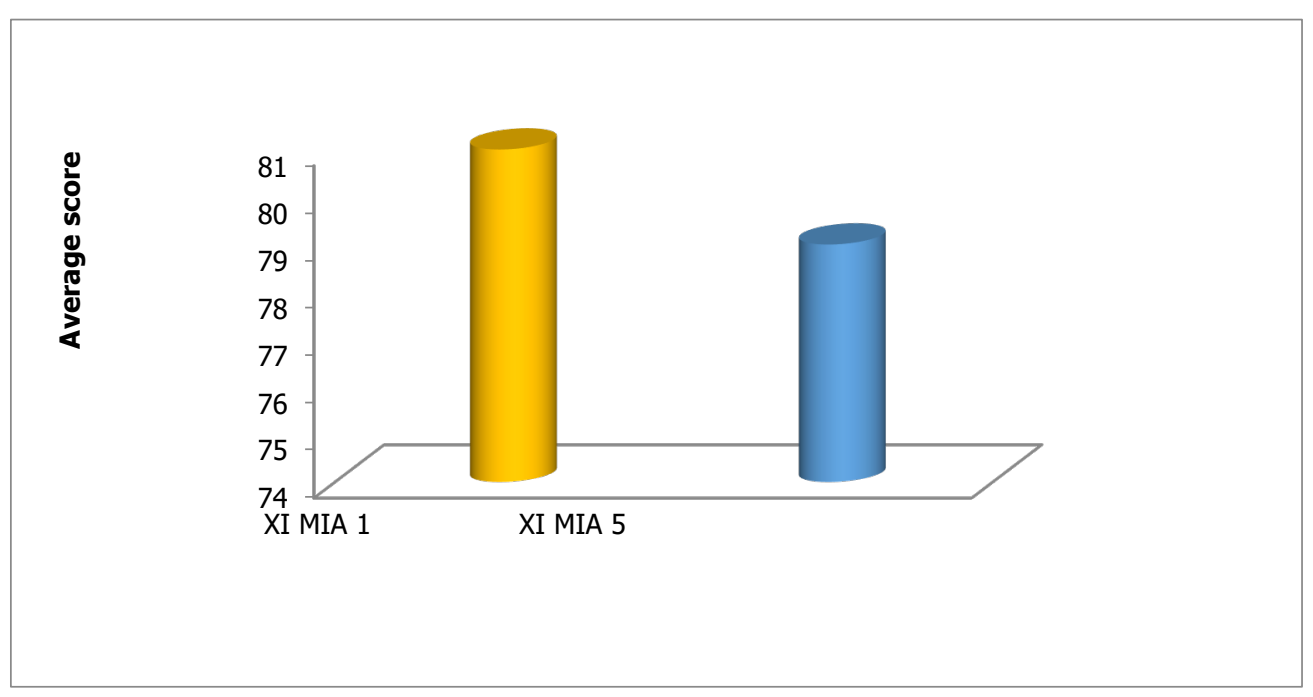

Figure 1. Students Psychomotor Data

Figure 1 shows the analysis result of psychomotor data for XI graders of SMAN 7 Palu in the learning of salt hydrolysis using POE model is categorized as good. It is caused by the analysis result categorized as skilled and highly skilled especially along the experiment. It implies that students are skilled to use the equipment and materials in accordance to the experimental procedure and able to observe the discoloration happened in litmus paper while experiment being conducted.

The ability of students in doing observation towards discoloration leads to the ability in classifying the solution into three categories; neutral, acidic or alkaline salt. 
The result of students psychomotor assessment for both classes show an unsignificant difference, both of student classes show good skill along the learning process including the experiment activity. It is appropriate to other research (Kearney, et.al., 2001) which stated that POE learning model is effective to understand the students towards abstract materials in order to increase the learning achievement. Through the implementation of POE learning model, scientific behavioral is suitable to be developed because the students become more critical and stimulate the curiosity towards the problems being faced. The students scientific behavioral would be appeared when they observe directly by conducting experiment.

\section{B. Analysis Result of Student Cognitive Competency Assessment}

The instrument of student cognitive competency assessment is given in the end of study for both of XI MIA 1 and its replication class. The data of final test assessment derived from XI MIA 1 has average score per student of 77 under deviation standard of 10.55, whilst the replication class has average score of 75 under deviation standard of 12.98 .

Normality test result for both classes are $\chi 2$ calculated $=4,44$ and $\chi 2$ table $=5,99$ and $\chi 2$ calculated $=4,23$ and $\chi 2$ table $=5,99$, whilst data homogenity analysis derives the value of Fcalculated of 1,29 and Ftable of 2,04 . The data shows both experiment classes are normal and homogen.

Based on those normality test result and homogenity, the research hypothesis test could adopt the parametric test. The research hypothesis test uses the value of $\alpha=0,05, \mathrm{dk}$ $=\mathrm{n}-1$, for X MIA 1 class, tcalculated is higher than ttable of $3,32>1,71$, whilst the replication class is $1,85>1,72$. According to the analysis result, the cognitive competency score achieved by students of SMAN 07 grade XI for salt hydrolysis material could be increased by the average score exceed 70 (minimum completeness score) after the POE model implementation.

The analysis result obtained by the samples show the difference of the clasical learning completeness for both of the classes. It is caused by the distinguishment of learning hours for chemistry study. In fact, chemistry study in a week for MIA 1 is held in the morning, whilst for the replication class is held in the afternoon. The distinguishment is able to trigger the low completeness score of learning for the entire students. The opinion is strengthened by research of Lestari (2015) who stated that students generally are more concentrate and focus when do learning in the morning under the reason of atmosphere to think being more focus and active to study. Vice versa, in afternoon, students have been tired of physical and mental and effected to the decrease of students interest.

The increase of students competency in learning the salt hydrolysis material, both competencies of psychomotor and cognitive in POE model implementation show the high active role of students to do experiment and the improvement of students behavioral along the study being conducted. It has been in accordance to the purpose of POE learning model which is to develop students activity and to increase students skill within the students knowledege aspect.

The implementation of POE learning model could encourage students to be more understand of the abstract concept because POE learning model requires the students to held direct observation towards the problems of salt hydrolysis material through experiments to generate the truth from initial hypothesis. In addition, the ability to correlate those three parts (Predict, Observe and Evaluate) could train the skill of critical thinking, especially 
skill to give a logical reasons. Khantavy and Yuenyong (2009) in his research stated that POE learning strategy provides new knowledges to the students in real and improve students participation to be more active and creative in order to increase the learning achievement significantly.

\section{Conclusion}

According to the result of the research could be concluded that:

1. The psychomotor competency of the students to plan and to conduct the experiment of salt hydrolysis could be increased both in XI MIA 1 class and XI MIA 5 shown by the achievement of determined criterias, skilled or highly skilled in doing experiment along POE learning process

2. Cognitive competency as a mirror of minimum basic competencies which is expected to be increased in both of the classes. It means that the POE learning model is suitable to be used to teach the salt hydrolysis based on the level of thinking of SMAN 7 Palu students to increase the minimum competencies.

\section{References}

Anisa, D. N., Masykuri, M., \& Yamtinah, S (2013). Pengaruh Model Pembelajaran POE (Predict, Observe, And Explanation) dan Sikap Ilmiah Terhadap Prestasi Belajar Siswa pada Materi Asam, Basa dan Garam Kelas VII Semester 1 SMA 1 Jaten”. Jurnal Pendidikan Kimia.2(2), 16-23.

Creswell, J.W. (2013). Research Design Pendekatan Kualitatif, Kuantitatif, dan Mixed (Edisi Ketiga). Yogyakarta: Pustaka Pelajar.

Lestari, I. (2013). Pengaruh Waktu Belajar dan Minat Belajar Terhadap Hasil Belajar Matematika. Journal Universitas Indraprasta PGRI. 3(2), 115-125.
Iqbalia, F. P. (2015). Analisis Keterampilan Proses Sains Siswa pada Model Pembelajaran Predict, Observe, Explain (POE) pada Materi Asam Basa. Skripsi. Jakarta: Universitas Islam Negeri Syarif Hidayatullah.

Johnstone, A. H. and Otis, K. H. (2005). Concept Mapping in Problem Based Learning: A Cautionary Tale. Journal of Royal Society of Chemistry. 7(2), 8495.

Khathanvy, H. \& Yuenyong, C. (2009). The Grade Student's Mental Model Of Force and Motion Through PredictObserve - Explain (POE) Strategy. Thailand: Khon Kaen University.

Malik, A. Kadarita, N. and Sofya, E. (2015). Efektivitas Pendekatan Saintifik dalam Meningkatkan Kemampuan Attributing pada Materi Hidrolisis Garam. Jurnal Pendidikan dan Pembelajaran Kimia. 4(2), 644-655.

Muslimah, E. and Nurdiniah, S. H. (2017). Mengambil Keputusan dengan Penerapan Model POE pada Materi Hidrolisis Garam Kelas XI-MIA 2 MAN KELUA Tahun Pelajaran 2016 / 2017. Jurnal Pendidikan Kimia. 1(1), 46-51.

Shofiah, R. I., Bektiarso, S. and Supriadi, B. (2017). Penerapan Model POE (Predict Observe Explain) dengan Metode Eksperimen Terhadap Hasil Belajar IPA dan Retensi Siswa di SMP. Jurnal Pembelajaran Fisika. 6(4), 356-363.

Sudesti, R., Fransisca, S. and Mimin, N. K. (2014). "Penerapan Pembelajaran Berbasis Praktikum untuk Meningkatkan Penguasaan Konsep dan Keterampilan Proses Sains Siswa SMP pada Subkonsep Difusi Osmosis". Formica Education Online. 1(1), 1-11. 